\title{
Effect of storage and processing of brazilian flaxseed on lipid and lignan contents
}

\author{
Efeito do armazenamento e do processamento da linhaça brasileira em seus teores de lipídios e lignanas \\ Renée Leão SIMBALISTA ${ }^{1}$, Karoline de Macêdo Gonçalves FROTA ${ }^{1}$, Rosana Aparecida Manólio SOARES ${ }^{1}$, \\ José Alfredo Gomes ARÊAS ${ }^{1 *}$
}

\begin{abstract}
Flaxseed has been widely studied around the world; its incorporation into products habitually consumed by human populations has been stimulated due to its unique nutritional value. The objective of this study was to evaluate the chemical composition of Brazilian flaxseed, to analyze the stability of lipids present in whole flaxseed flour (WFF) or partially defatted flaxseed flour (DFF) stored under several temperatures,

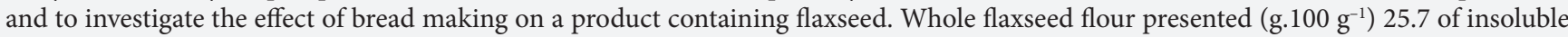
fiber, 10.7 of soluble fiber, 38.9 of lipids, and 2.65 of lignan. Defatted flaxseed flour presented 65\% less lipids, 36\% more fiber and 56\% more lignan than whole flaxseed flour. The fatty acid profile was maintained in the defatted flaxseed flour, and it presented a stable composition during storage under ambient temperature, refrigeration, and freezing. The fatty acid profile was similar in the bread containing defatted flaxseed flour after dough development, baking, and storage at room temperature or refrigerated. After baking, $89 \%$ of the lignan content was kept in bread. Results show that Brazilian flaxseed has an interesting chemical composition, and that defatted flaxseed, by-product of lipid extraction, presents a good stability to grind and storage under several temperatures. Thus, defatted flaxseed flour can be incorporated in bread, increasing its nutritional and functional value.
\end{abstract}

Keywords: flaxseed; lignan; fatty acids' profile; stability to process and storage.

\section{Resumo}

A semente de linhaça vem sendo estudada por pesquisadores em todo o mundo; sua incorporação em produtos habitualmente consumidos pela população vem sendo estimulada devido a seu destacado valor nutricional. Objetivos: avaliar a composição da linhaça brasileira, analisar a estabilidade dos lipídios presentes na farinha de linhaça integral (WFF) ou na farinha parcialmente desengordurada (DFF), estocadas sob diferentes temperaturas, e investigar o efeito do processamento em pão contendo linhaça. A farinha de linhaça integral apresentou ( $\mathrm{g}$. $100 \mathrm{~g}^{-1}$ ): 25,7 de fibra insolúvel, 10,7 de fibra solúvel, 38,9 de lipídios e 2,65 de lignana. A farinha parcialmente desengordurada apresentou 65\% menos lipídios, 36\% mais fibra e 56\% mais lignana, comparado a farinha de linhaça integral. O perfil de ácidos graxos foi mantido em DFF. A composição da farinha parcialmente desengordurada permaneceu estável durante o armazenamento sob temperaturas ambiente, refrigeração e congelamento. O perfil de ácidos graxos foi similar no pão contando DFF após o crescimento da massa, o cozimento e a estocagem às temperaturas ambiente ou de refrigeração. Após a cocção, $89 \%$ do conteúdo de lignana foi mantido no pão. Os resultados demonstram que a linhaça brasileira parcialmente desengordurada, subproduto da extração lipídica, apresenta estabilidade a moagem e estocagem sob diferentes temperaturas. Assim, a farinha parcialmente desengordurada pode ser incorporada a pães para incrementar seu valor nutricional e funcional. Palavras-chave: linhaça; lignana; perfil de ácidos graxos; estabilidade ao processamento e armazenamento.

\section{Introduction}

Flaxseed (Linum usitatissimum L.), also known as linseed, is an edible oilseed that was significantly consumed prior to the industrial revolution (THOMPSON, 1995). However, due to its limited shelf-life, flaxseed was not used for human nutrition for a period of time. However, nowadays it gains attention worldwide as a functional food due to the findings that the consumption of flaxseed brings benefits to health, such as to help reducing the risk of occurrence of breast cancer, osteoporosis, diabetes, heart disease, and menopausal symptoms (DUFFY; CYR, 2003; DODIN et al., 2008; SACCO et al., 2009; THAKUR et al., 2009).

In Brazil, few studies have been carried out to examine the composition of national seed, the brown flaxseed, and its effect on health (UNIVERSIDADE..., 2006; SANTOS; AZEREDO; MARTINS, 2007; MACIEL; PONTES; RODRIGUES, 2008;
CARDOZO et al., 2010; ROSA et al., 2010; SIMBALISTA et al., 2010). However, around the world, these studies are frequent, and the benefits were found to be related to flaxseed unique nutrient profile that includes a high concentration of three bioactive compounds, fiber, lignans, and $\alpha$-linolenic fatty acid (ALA) (INSTITUTE..., 1998; SCIARRA; TOSCANO, 2000; THOMPSON, 2003).

The fiber is associated to phytoestrogen precursors called lignans present in the outer wall of the flaxseed. The high soluble fiber content is interesting for the nutritional point of view because it may decrease postprandial glucose absorption, improve glucose tolerance, and modulate serum cholesterol levels (CUNNANE et al., 1995; RICKARD; THOMPSON, 1997; THAKUR et al., 2009).

\section{Received 17/9/2010}

Accepted 2/1/2012 (005064)

${ }^{1}$ Faculdade de Saúde Pública, Universidade de São Paulo - USP, Av. Doutor Arnaldo, 715, Cerqueira Cesar, CEP 01246-904, São Paulo, SP, Brasil, e-mail: jagareas@usp.br

${ }^{*}$ Corresponding author 
Flaxseed contains great concentration of lignans, 12 to 1500 times more than that observed in other fruits, vegetables, nuts, legumes, and grains in which they are found in significantly lesser amounts (MEAGHER; BEECHER, 2000; WESTCOTT; MUIR, 1996). Plant lignans are phenolic compounds whose carbohydrate conjugate is removed by intestinal bacteria to form the bioactive mammalian lignans, enterodiol, and enterolactone. These lignans are absorbed in the small intestine and conjugated in the liver. Flaxseed is the richest known source of the main mammalian lignan precursor, secoisolariciresinol diglucoside (SDG). SDG may affect the cancer incidence by altering production and metabolism of steroid hormones and their action at the cellular level (HUTCHINS et al., 2001; ADLERCREUTZ, 2007).

The oil in flaxseed is composed mainly of polyunsaturated fatty acids (PUFA). It is the richest known vegetable source of $\alpha$-linolenic acid (ALA), usually found in cold-water fish (SHAHIDI; WANASUNDARA, 1998), but it lacks in Western diets (DAUN; BARTHET; CHORNICK, 2003; MORRIS, 2001; CARTER, 1993). Due to its unsaturation, ALA is subject to rapid and/or extensive oxidation by exposure to air, light, or temperature resulting in potential alteration in the nutritional composition and quality of food. The production of oxidized compounds, such as lipid peroxides, leads to a reduced shelf life (CHEN; RATNAYAKE; CUNNANE, 1994; ALAMED; McCLEMENTS; DECKER, 2006; BORAN; KARAÇAM; BORAN, 2006; DRUSCH et al., 2007; MORIYA et al., 2007).

Due to nutritional and functional aforementioned reasons and anticipating a future consumption of this ingredient, it becomes necessary to evaluate whether it is feasible in terms of stability, to incorporate the flaxseed flour as an ingredient of bread, given that during bread making the levels of bioactive compounds in cereal grains may decrease (SLAVIN; JACOBS; MARQUART, 2001).

The objectives of the present study were to examine the chemical composition of the Brazilian flaxseed, to verify the oxidative stability of ground flaxseed under various conditions of temperature and storage, and to evaluate the effect of storage and processing when flaxseed flour is incorporated into bread.

\section{Materials and methods}

\subsection{Chemical composition of flaxseed}

Two types of products usually found in the national market were selected: whole flaxseed and partially defatted flaxseed flour, a by-product of oil extraction by cold pressing process. Whole flaxseeds and seeds used for partially defatted flaxseed flour production were cultivated in Rio Grande do Sul State, Brazil.

For the following analyses, proximate composition, fatty acid profiles, and SDG determination, whole seeds were ground using a hammer mill (MML-100, Astecma, São Paulo, Brazil) to obtain the whole flaxseed flour (WFF). Partially defatted flaxseed flour (DFF) donated by Pazze, a vegetable oil industry (Panambi, Rio Grande do Sul, Brazil).

\section{Proximate composition}

The official methods of the Association of Official Analytical Chemists - AOAC (2000) were used in the proximate analysis. Moisture and ash contents were determined gravimetrically; total protein was determined by the Kjeldahl method $(\mathrm{N} \times 6.25)$; fat was determined by petroleum ether extraction in a Soxhlet apparatus; and crude fiber and soluble and insoluble fractions were determined by an enzymatic-gravimetric method (PROSKY et al., 1988). Carbohydrates were calculated by the difference of the sum of protein, lipid, ashes, and fiber from 100. Caloric value was estimated by ATWATER coefficients: $4 \mathrm{kcal}$ $(16.8 \mathrm{~kJ}) \cdot \mathrm{g}^{-1}$ for proteins, $4 \mathrm{kcal}(16.8 \mathrm{~kJ}) \cdot \mathrm{g}^{-1}$ for carbohydrates, and $9 \mathrm{kcal}(37.7 \mathrm{~kJ}) \cdot \mathrm{g}^{-1}$ for lipids (WATT; MERRILL, 1963).

\section{Fatty acid profile}

Lipids were extracted using the dry column methodology suggested by Marmer and Maxwell (1981). Ten milliliters of the dry column extract were transferred to a pre-weighed beaker and evaporated under a stream of nitrogen. Next, the extract was placed in a stove at $105{ }^{\circ} \mathrm{C}$ and, after 3 hours, cooled in a desiccator and weighed. Lipid extract was submitted to cold saponification and methylation with $\mathrm{BF}_{3}$ in methanol (METCALFE; SCHMITZ; PELKA, 1966). Fatty acid analysis was performed in a gas chromatograph (CP9002, Chrompack, New Jersey, USA) with split injector (1:67 split ratio), flame ionization detector, and capillary column of fused silica CP-SIL 88 (50 m; $0.25 \mathrm{~mm}$ and $0.25 \mu \mathrm{m})$. The temperature of the injection port was $270{ }^{\circ} \mathrm{C}$, and that of the detector was $300^{\circ} \mathrm{C}$. The initial oven temperature was $100^{\circ} \mathrm{C}$ followed by an increase to $240^{\circ} \mathrm{C}$ at a rate of $5^{\circ} \mathrm{C} /$ minute. The carrier gas was hydrogen at $1.2 \mathrm{~mL} / \mathrm{minute}$. The identification of the fatty acids was achieved by comparing their retention times with those of the fatty acid methyl ester mixture \#189-19, which was used as quantitative external standards.

\section{SDG content}

The flaxseed flour was analyzed for SDG content, according to Coulman et al. (2005). Briefly, the ground sample was defatted with hexane $(1: 5 \mathrm{w} / \mathrm{v})$ threefold, and the lignans in the defatted ground samples were extracted with $70 \% \mathrm{MeOH}$ at $60^{\circ} \mathrm{C}$. The extract was evaporated, hydrolyzed with $\mathrm{NaOH} 1 \mathrm{~mol} . \mathrm{L}^{-1}$, and then neutralized with acetic acid 1 mol.L $\mathrm{L}^{-1}$. The lignanrich fraction was eluted using C18 reversed-phase octadecyl bonded silica (C18) extraction columns (Scientific Products and Equipment, Ontario, Canada) for salt removal, dried at $60{ }^{\circ} \mathrm{C}$, and redissolved in a sodium acetate buffer. After overnight, enzyme hydrolysis with $\beta$-glucuronidase (Helix pomatia, Sigma Chemical, Missouri, USA) at $37^{\circ} \mathrm{C}$, the samples were again passed through a $\mathrm{C} 18$ column for salt removal, dried at $60^{\circ} \mathrm{C}$ and redissolved in $\mathrm{MeOH}$. The internal standard $5 \alpha$-androstane$3 \beta, 17 \beta$-diol (Steraloids, New Hampshire, USA) was added, $\mathrm{MeOH}$ was evaporated under nitrogen, and the lignans were derivatized (Tri-Sil Reagent HMDS/TMCS in pyridine 2:1:10, Pierce, Illinois, USA) for 30 minutes at $60^{\circ} \mathrm{C}$. The reagent was removed under nitrogen; the sample was dissolved in hexane. The samples were analyzed by GC-MS (GC 6890 Series II, MS 5973, Hewlett-Packard, Pennsylvania, USA) equipped with 
HP- $5 \mathrm{~ms}$ capillary column $(25 \mathrm{~m} \times 0.12 \mathrm{~mm} \times 0.25 \mu \mathrm{m})$. The temperature of the injection port was $280^{\circ} \mathrm{C}$. The initial oven temperature was $100{ }^{\circ} \mathrm{C}$ for 1 minute, followed by an increase to $280{ }^{\circ} \mathrm{C}$ at a rate of $25^{\circ} \mathrm{C} /$ minute. The carrier gas was helium at $1 \mathrm{~mL} /$ minute. The volume injection was $1 \mu \mathrm{L}$.

This analysis was performed in the Department of Nutrition Sciences, Faculty of Medicine University of Toronto, Canada.

\subsection{Effect of storage on partially defatted flaxseed flour (DFF) lipid oxidation}

The following analyses were performed immediately after DFF acquisition $\left(\mathrm{T}_{0}\right)$. Upon receive, DFF was stored at room temperature $\left(25^{\circ} \mathrm{C}\right)$, refrigerated $\left(5^{\circ} \mathrm{C}\right)$ or frozen $\left(-12^{\circ} \mathrm{C}\right)$ in polyester and polyethylene golden foiled bags protected from air and light. Each package contained, in average, $80 \mathrm{~g}$ of DFF. The same analyses were carried out after 14 days of storage.

\section{Fatty acid profile}

The analysis was performed as described in 2.1.2.

\section{TBARs determination}

Thiobarbituric acid reactive substances (TBARS) determination was performed using the extraction method proposed by Vyncke (1975). The 1,1,3,3-tetraethoxypropane was used as standard. Absorbance reading was taken at $538 \mathrm{~nm}$ using a Cecil Brand spectrophotometer model 1020. The values found were interpreted as mg of 2-thiobarbituric acid reactive substances per $1000 \mathrm{~g}$ of sample.

\subsection{Development and analysis of a bread containing DFF}

\section{Bread making}

The bread (Table 1) was prepared and produced in an industrial bakery of "Fundação de Desenvolvimento da Panificação e Confeitaria" (Foundation for the Development of the Bakery and Confectionery) (FUNDIPAN, São Paulo, Brazil). Gluten addition was necessary to improve the bakery characteristics of the bread since flaxseed contains a great quantity of fiber.

White bread was prepared by using a semi-quick planetary mixer of two-speed transmission (35 and $240 \mathrm{rpm}$ ). After achieving ripe stage (verified by the dough apparent rheology by an experienced baker), the dough was divided into $800 \mathrm{~g}$ portions, modeled, and allowed to ferment into appropriate trays in a temperature-controlled fermentation chamber $\left(33^{\circ} \mathrm{C}\right)$ for 45 minutes. An air circulating oven was used to bake the breads at $160{ }^{\circ} \mathrm{C}$ for 45 minutes. After baking, the breads were allowed to cool to ambient temperature.

After 24 hours at the ambient temperature, it was sliced and packaged with two slices per package in polyester and polyethylene golden foiled bags to protect it from air and light. Each package contained, in average, $80 \mathrm{~g}$ of bread.

\section{Effect of processing on SDG}

In order to verify the stability of lignan, the dough was analyzed before and after its growth. SDG content in bread
Table 1. Bread ingredients and proportions

\begin{tabular}{lc}
\hline Ingredients & Quantities $\left(\mathrm{g} .100 \mathrm{~g}^{-1}\right)$ \\
\hline Flour mix & 49.1 \\
Sugar & 2.7 \\
Salt & 1.0 \\
Oil & 2.5 \\
Emulsifyer & 0.5 \\
Dried yeast & 1.0 \\
Water & 39.3 \\
Gluten (80\% purity) & 3.9 \\
\hline
\end{tabular}

${ }^{\star}$ Proportion $-73 \%$ wheat flour: $27 \%$ DFF.

Table 2. Proximate composition ( $\left.\mathrm{g} .100 \mathrm{~g}^{-1}\right)$ and caloric value (kcal.100 g $\mathrm{g}^{-1}$ ) of WFF and DFF samples.

\begin{tabular}{lcc}
\hline \multicolumn{1}{c}{ Nutrient } & WFF & DFF \\
\hline Moisture $\left(\mathrm{g} .100 \mathrm{~g}^{-1}\right)$ & $4.7^{\mathrm{a}}(0.3)$ & $9.6^{\mathrm{b}}(0.1)$ \\
Ash $^{\star}\left(\mathrm{g} .100 \mathrm{~g}^{-1}\right)$ & $4.1^{\mathrm{a}}(0.5)$ & $4.9^{\mathrm{a}}(0.1)$ \\
Protein $^{*}\left(\mathrm{~g} .100 \mathrm{~g}^{-1}\right)$ & $21.6^{\mathrm{a}}(0.3)$ & $33.4^{\mathrm{b}}(0.6)$ \\
Lipids $^{*}\left(\mathrm{~g} .100 \mathrm{~g}^{-1}\right)$ & $38.9^{\mathrm{b}}(0.5)$ & $16.8^{\mathrm{a}}(0.2)$ \\
Fiber & & \\
Insoluble $\left(\mathrm{g} .100 \mathrm{~g}^{-1}\right)$ & $25.7^{\mathrm{a}}(1.5)$ & $35.0^{\mathrm{b}}(2.0)$ \\
Soluble $\left(\mathrm{g} .100 \mathrm{~g}^{-1}\right)$ & $10.7^{\mathrm{a}}(1.5)$ & $14.6^{\mathrm{a}}(1.5)$ \\
Caloric value $^{*}\left(\mathrm{kcal}^{\left.100 \mathrm{~g}^{-1}\right)}\right.$ & $436.5[1827.5 \mathrm{~kJ}]$ & $284.8[1192.4 \mathrm{~kJ}]$ \\
\hline
\end{tabular}

Values were expressed as average (standard deviation) of three determinations. Means in the same line that do not share the same letter are significantly different $(\mathrm{p}<0.05)$. ${ }^{*}$ Dry matter basis.

Table 3. SDG content in WFF and DFF samples on a dry matter basis.

\begin{tabular}{cc}
\hline Sample & SDG content $\left(\mathrm{g} .100 \mathrm{~g}^{-1}\right)$ \\
\hline WFF & $2.65^{\mathrm{a}}(0.42)$ \\
DFF & $4.18^{\mathrm{b}}(0.27)$ \\
\hline Values were expressed
\end{tabular}

Values were expressed as mean (standard deviation) of two determinations. Means that do not share the same letter are significantly different $(\mathrm{p}<0.05)$.

after baking was also verified. Before analysis, all samples were dehydrated by freeze-drying.

The analysis was performed as described in 2.1.3.

Effect of processing and storage on fatty acids

The samples were collected before and after baking, and after seven days of storage. Storage was performed in two different temperatures, at room temperature $\left(25^{\circ} \mathrm{C}\right)$ or refrigerated $\left(5^{\circ} \mathrm{C}\right)$.

Lipids extraction and fatty acid profile were performed as described in 2.1.2.

\section{Statistical analysis}

The results were expressed as mean values \pm standard deviations. Comparison of means was performed by Student's t-test or one-way analysis of variance (ANOVA) followed by Tukey's test with significance defined at the $\mathrm{p}<0.05$ level. Statistical analyses were performed using the SPSS 15.0 software (SPSS Institute, North Carolina, USA). 


\section{Results e discussion}

\subsection{Chemical composition of flaxseed}

The results for proximate composition of samples WFF and DFF are presented in Table 2.

Variations on flaxseed composition occur due to species variety, soil, and climate characteristics during seed growth or methods used in chemical determinations (DAUN; BARTHET; CHORNICK, 2003). Despite that, lipids, protein, and ash contents in Brazilian flaxseed were close to those found in Canadian (OOMAH; MAZZA, 1998; BOZAN; TEMELLI, 2008) and American flaxseed (HETTIARACHCHY et al., 1990).

Practically, all carbohydrates in flaxseed are dietary fibers, which are considered a source of soluble and insoluble fractions. According to Daun, Barthet and Chornick, 2003, the soluble/ insoluble rate can vary from 20:80 to 40:60 in flaxseed. This study found the rate of 29:71 (soluble/insoluble fibers) for WFF and DFF.

Due to cold-press, DFF presents higher protein and fiber and lower lipid contents compared to those of WFF, as expected. The defatting process of the flour caused a reduction in $35 \%$ of the calorie value.

The contents of SDG in the flaxseed extract were determined and the results on a dry matter basis are shown in Table 3.

There was a large variability in the SDG concentration of WFF and DFF. In the study of Li et al. (2008), SDG content was found to be $1.54 \%$ in the defatted flaxseed powder on a dry matter basis. This result is in agreement with previous findings, in which SDG content varied between 0.6 and $2.9 \%$ in the defatted flaxseed powder (JOHNSSON et al., 2002; BEEJMOHUN et al., 2007). Struijs et al. (2007) obtained 7.5\% of the lignan macromolecule from $400 \mathrm{~g}$ of flaxseed hulls indicating that flaxseed hulls were enriched in SDG compared to the cotyledons.

Main fatty acids of WFF and DFF analyzed are presented in Table 4.

Brazilian flaxseed presents $13 \%$ of saturated fatty acids, about $22 \%$ of monounsaturated fatty acids, and $65 \%$ of polyunsaturated linoleic plus $\alpha$-linolenic (ALA) fatty acids. Fatty acid profile was not affected by cold-pressing.

The major content of lipids is represented by ALA. Flaxseed is the most important vegetable source of n-3 fatty acids. The percent of fat as ALA in flaxseed is 5.5 times higher than that in the next-highest sources, walnuts, and canola oil (GEBAUER et al., 2006).

According to Hettiarachchy et al. (1990), flaxseed contains $32-45 \%$ of oil, of which $51-55 \%$ is $\alpha$-linolenic acid ( $n-3$ fatty acid) and $15-18 \%$ is linoleic acid. The results of this study were slightly lower than those of previous reports, which found 53 to 58\% of ALA (OOMAH; MAZZA, 1997; BOZAN; TEMELLI, 2008). Unsaturation levels can vary due to temperature during growth; seeds from colder lands usually present a greater amount of unsaturated fatty acids (DAUN; BARTHET;
Table 4. Fatty acid profile of WFF and DFF samples.

\begin{tabular}{cccccc}
\hline Sample & $\begin{array}{c}\text { Palmitic } \\
\text { C16:0 }\end{array}$ & $\begin{array}{c}\text { Stearic } \\
\text { C18:0 }\end{array}$ & $\begin{array}{c}\text { Oleic } \\
\text { C18:1 }\end{array}$ & $\begin{array}{c}\text { Linoleic } \\
\text { C18:2 }\end{array}$ & $\begin{array}{c}\alpha \text {-Linolenic } \\
\text { C18:3 }\end{array}$ \\
\hline WFF & $6.9^{\mathrm{a}}(0.2)$ & $5.8^{\mathrm{a}}(0.2)$ & $22.4^{\mathrm{a}}(0.6)$ & $14.0^{\mathrm{a}}(0.1)$ & $50.9^{\mathrm{a}}(1.1)$ \\
DFF & $6.6^{\mathrm{a}}(0.1)$ & $5.6^{\mathrm{a}}(0.1)$ & $22.4^{\mathrm{a}}(0.1)$ & $13.7^{\mathrm{a}}(0.1)$ & $51.7^{\mathrm{a}}(0.3)$ \\
\hline
\end{tabular}

Values were expressed as average (standard deviation) of two determinations. Means in the same column that do not share the same letter are significantly different $(\mathrm{p}<0.05)$.

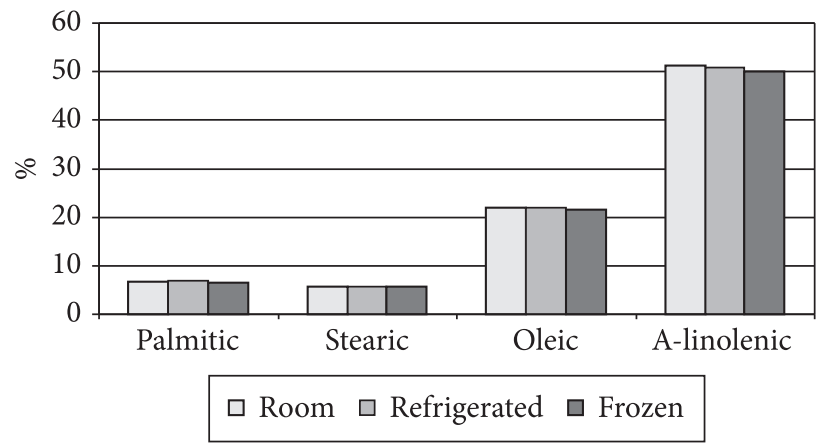

Figure 1. Percentage of the main fatty acids contained in samples.

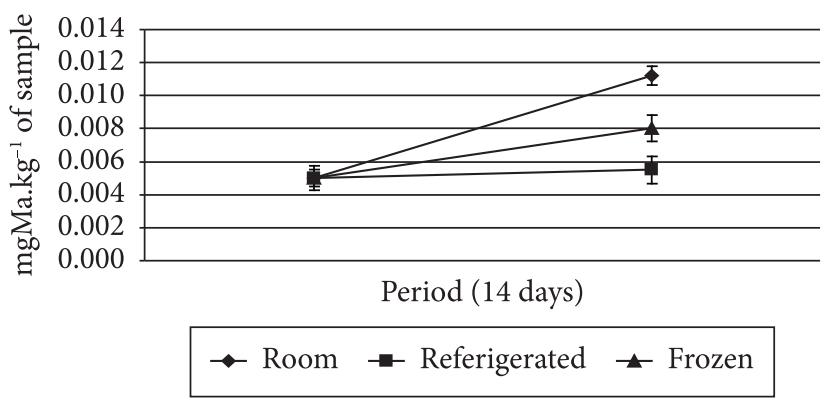

Figure 2. TBARS concentration (mg. $\mathrm{kg}^{-1}$ of sample) of three determinations in DFF stored under different temperatures over fourteen days.

CHORNICK, 2003), which could explain this difference since weather in Brazil is typically tropical.

Simopoulos, Leaf and Salem Junior (2000) reported $2.22 \mathrm{~g} /$ day of ALA as the adequate intake (AI) for adults. Therefore, an adult would have to consume approximately $13 \mathrm{~g}$ of WFF or $30 \mathrm{~g}$ of DFF to meet this requirement.

The defatted meal, which is the residue after extraction of flaxseed oil, has been used as livestock feed, and little attention has been given to its chemical properties. This study demonstrated that the use of DFF brings advantages such as lower lipid quantities, which maintains its fatty acid profile, lower caloric value, and increased SDG content comparing to WFF.

\subsection{Effect of storage on DFF lipid oxidation}

Whole flaxseed remains stable in terms of lipid oxidation for many years; however, cold-pressing and high moisture conditions during storage can trigger enzymatic-promoted oxidation. Since limited knowledge is available, further research 
is required with regard to shelf life and cold-pressing operations (HALL; TULBEK; XU, 2006). Thus, this work aimed to study the lipid stability of DFF stored under several temperatures.

Figure 1 shows the fatty acid profile of DFF after fourteen days of storage.

Fatty acid profile remained unchanged during DFF storage $(p>0.05)$. As observed, a fourteen-day storage showed that sample was stable at room, refrigerated, and frozen temperatures. This storage period was not enough to degrade $\alpha$-linolenic acid at different temperatures. Flaxseed contains different phenolic and antioxidant substances that may play a protective role in lipid oxidation (KITTS et al., 1999; KRAUSHOFER; SONTAG, 2002).

In contrast, the TBARS assay allowed a differentiation in oxidative stability of DFF samples. After about fourteen days of storage, an increase in the amount of radicals can be observed for flaxseed, especially at room temperature (Figure 2). The amount of TBARS of frozen flaxseed was the lowest observed among the different kinds of storage.

Despite the lower stability at room temperature, the final concentration of malonaldehyde in the sample stored for fourteen days was still small compared to the values found in powder milk (0.52 mgMA. $\left.\mathrm{kg}^{-1}\right)$, cheese $\left(0.09 \mathrm{mgMA} . \mathrm{kg}^{-1}\right)$, butter $\left(0.12 \mathrm{mgMA} . \mathrm{kg}^{-1}\right)$, and bacon $\left(0.8 \mathrm{mgMA} . \mathrm{kg}^{-1}\right)$ that exhibited good shelf life (TORRES; OKANI, 1997).

Malcolmson, Przybylski and Daun (2000) found that milled flaxseed is stable over 33 days of storage at $23 \pm 2{ }^{\circ} \mathrm{C}$ by measuring peroxide values, free fatty acids, conjugated double bonds, and volatile compounds. In the same study, panelists were not able to detect a difference in the odor characteristics between the fresh or stored flaxseed samples. Flaxseed contains a large number of phenolic and other antioxidant compounds that may act as protective factors against lipid oxidation (KRAUSHOFER; SONTAG, 2002).

\subsection{Development and analysis of a bread containing DFF}

Table 5 shows the SDG content in different steps of the production of bread.

Data on the lignans from processed foods containing flaxseed are limited despite the increased use of flaxseed (NESBITT; THOMPSON, 1997; RICKARD et al., 1998). In the present study, it was possible to observe that SDG content changes after fermentation, probably because microorganisms and their enzymes metabolized SDG in enterodiol and enterolactone. After baking, $89 \%$ of the SDG content was kept in the bread.

The fatty acid profile of the crude bread, baked bread, bread baked and stored for seven days at room temperature, and bread baked and stored for seven days under refrigeration is presented in Figure 3.

The results show that processing and storage apparently did not interfere in the fatty acid profile of breads. Some studies (CUNNANE et al., 1994; MANTHEY; LEE; HALL, 2002) confirmed the stability of ALA in bread products since heat is
Table 5. Effect of processes on the SDG content of the bread prepared.

\begin{tabular}{|c|c|c|c|}
\hline$\% \mathrm{SDG}$ & 1 & 2 & 3 \\
\hline Dry basis & $0.54^{\mathrm{b}}(0.02)$ & $0.40^{\mathrm{a}}(0.01)$ & $0.35^{\mathrm{a}}(0.01)$ \\
\hline Wet basis & $0.26^{\mathrm{b}}(0.01)$ & $0.19^{\mathrm{a}}(0.01)$ & $0.18^{\mathrm{a}}(0.01)$ \\
\hline
\end{tabular}

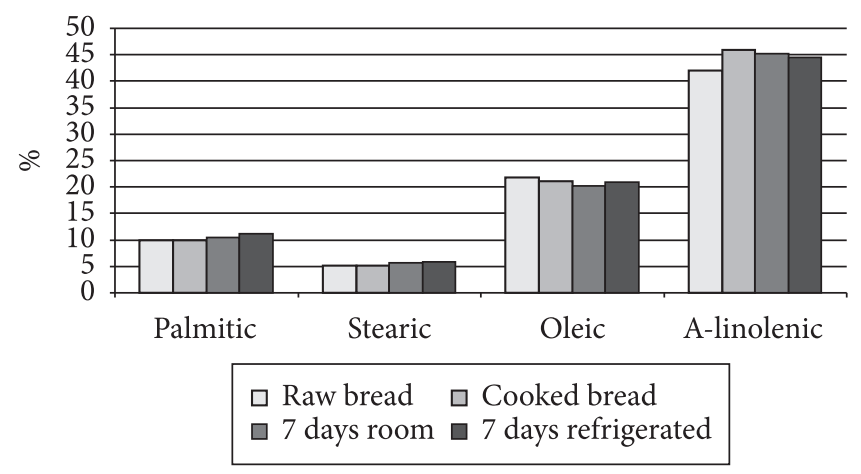

Figure 3. Percentage of fatty acids in raw bread, cooked bread, bread stored after 7 days in room temperature and bread stored after 7 days under refrigeration.

transferred to the product in an indirect way. Chen, Ratnayake and Cunnane (1994) produced muffins containing $28.5 \%$ of flaxseed. These authors verified that the ALA content did not change after two hours of baking at $178^{\circ} \mathrm{C}$.

Cunnane et al. (1993) compared the plasma fatty acid profile from women who consumed $50 \mathrm{~g}$ of flaxseed to that of women who consumed the equivalent amount of flaxseed in bread. After four weeks of consumption, no difference was found between these groups.

For nutritional interventions, it is necessary to offer a food product that is similar to that population habitually consume. Therefore, flaxseed bread is an important product to enrich nutritionally the habitual diet and to introduce potentially health promoters such as the lignans.

\section{Conclusions}

Brazilian flaxseed is a rich source of n-3 fatty acids and SDG. No changes were observed in the fatty acid profile after cold press. Nevertheless, DFF presented lower lipid quantities, lower caloric value, and increased SDG content compared to those of WFF.

This study reported the stability of ground flaxseed, either alone or as an ingredient in bread, under various conditions of temperature and during several days. A great part of the SDG content is also stable during the dough and heat treatment of the bread.

As a result, Brazilian flaxseed and its defatted product may be stored and used as a feasible alternative to food product enrichment. 


\section{Acknowledgements}

The authors are grateful to Dr. Lilian Thompson (Toronto University, Canada) for the identification and quantification of the SDG, and for the financial support provided by The State of São Paulo Research Foundation (FAPESP).

\section{References}

ADLERCREUTZ, H. Lignans and human health. Critical Reviews in Clinical Laboratory Science, v. 44, n. 5-6, p. 483-525, 2007. PMid:17943494. http://dx.doi.org/10.1080/10408360701612942

ALAMED, J.; McCLEMENTS, D. J.; DECKER, E. A. Influence of heat processing and calcium ions on the ability of EDTA to inhibit lipid oxidation in oil-in-water emulsions containing omega-3 fatty acids. Food Chemistry, v. 95, p. 585-590, 2006. http://dx.doi. org/10.1016/j.foodchem.2005.01.041

ASSOCIATION OF OFFICIAL ANALYTICAL CHEMISTS - AOAC. Official Methods of Analysis. 17th. ed. Arlington: AOAC Inc., 2000.

BEEJMOHUN, V. et al. Microwave-assisted extraction of the main phenolic compounds in flaxseed. Phytochemical Analysis, v. 18, n. 4, p. 275-282, 2007. PMid:17623361. http://dx.doi.org/10.1002/ pca. 973

BORAN, G.; KARAÇAM, H.; BORAN, M. Changes in the quality of fish oils due to storage temperature and time. Food Chemistry, v. 98, p. 693-698, 2006. http://dx.doi.org/10.1016/j.foodchem.2005.06.041

BOZAN, B.; TEMELLI, F. Chemical composition and oxidative stability of flax, safflower and poppy seed and seed oils. Bioresource and Technology, v. 99, p. 6354-6359, 2008. PMid:18198133. http:// dx.doi.org/10.1016/j.biortech.2007.12.009

CARDOZO, L. F. et al. Exposure to flaxseed during lactation does not alter prostate area or epithelium height but change lipid profile in rats. Nutrición Hospitalaria, v. 25, p. 250-255, 2010.

CARTER, J. F. Potential of flaxseed and flaxseed oil in baked goods and other products in human nutrition. Cereal Foods World, v. 38, p. 753-759, 1993.

CHEN, Z. Y.; RATNAYAKE, W. M. N.; CUNNANE, S. C. Oxidative stability of flaxseed lipids during baking. Journal of American Oil and Chemists Society, v. 71, p. 629-632, 1994. http://dx.doi. org/10.1007/BF02540591

COULMAN, K. D. et al. Whole Sesame Seed Is as Rich a Source of Mammalian Lignan Precursors as Whole Flaxseed. Nutrition and Cancer, v. 52, n. 2, p. 156-165, 2005. PMid:16201847. http://dx.doi. org/10.1207/s15327914nc5202_6

CUNNANE, S. C. et al. Nutritional Attributes of Traditional Flaxseed in Healthy Young Adults. American Journal of Clinical Nutrition, v. 61, p. 62-8, 1995.

CUNNANE, S. C. et al. High $\alpha$-linolenic acid flaxseed: some nutritional properties in humans. British Journal of Nutrition v. 69, p. 443-453, 1993. http://dx.doi.org/10.1079/BJN19930046

CUNNANE, S. C. et al. Nutritional Attributes of traditional flaxseed in health young adults. American Journal of Clinical Nutrition, v. 61, p. 62-68, 1994.

DAUN, J. K.; BARTHET, V. J.; CHORNICK T. L.; Duguid S. Structure, composition and variety development of flaxseed. In: CUNNANE, S. C.; THOMPSON, L. U. (Eds.). Flaxseed in Human Nutrition. Champaign: AOCS Press, 2003. p. 1-40.

DODIN, S. et al. Flaxseed on cardiovascular disease markers in healthy menopausal women: a randomized, double-blind, placebocontrolled trial. Nutrition, v. 24, p. 23-30, 2008. PMid:17981439. http://dx.doi.org/10.1016/j.nut.2007.09.003
DRUSCH, S. et al. Impact of physicochemical characteristics on the oxidative stability of fish oil microencapsulated by spray-drying. Journal of Agricultural and Food Chemistry, v. 55, p. 11044-11051, 2007. PMid:18038994. http://dx.doi.org/10.1021/jf072536a

DUFFY, C.; CYR, M. J. Phytoestrogens: Potential benefits and implications for breast cancer survivors. Women's Health, v. 12, p. 617-631, 2003. PMid:14583103. http://dx.doi. org/10.1089/154099903322404276

GEBAUER, S. K. et al. n-3 fatty acid dietary recommendations and food sources to achieve essentiality and cardiovascular benefits. American Journal of Clinical Nutrition, v. 83, p. 1526S-1535S, 2006. PMid:16841863.

HALL, C.; TULBEK, M. C.; XU, Y. Flaxseed quality and end use functionality. Advances in food and nutrition research, v. 51, p. 47-75, 2006.

HETTIARACHCHY, N. S. et al. Chemical composition of 11 flaxseed varieties grown in North Dakota. Proceedings of the 53rd Flax Institute, v. 53, p. 36, 1990.

HUTCHINS, A. M. et al. Flaxseed consumption influences endogenous hormone concentrations in postmenopausal women. Nutrition and Cancer, v. 39, p. 58-65, 2001. PMid:11588903. http://dx.doi. org/10.1207/S15327914nc391_8

INSTITUTE OF FOOD TECHNOLOGISTS - IFT. Expert Panel on Food Safety and Nutrition. Functional foods: their role in disease prevention and health promotion. Food Technology. v. 52, p. 63-70, 1998.

JOHNSSON, P. et al. Polymeric fractions containing phenol glucosides in flaxseed. Food Chemistry, v. 76, n. 2, p. 207-212, 2002. http:// dx.doi.org/10.1016/S0308-8146(01)00269-2

KITTS, D. D. et al. Antioxidant activity of the flaxseed lignan secoisolariciresinol diglycoside and its mammalian lignan metabolites enterodiol and enterolactone. Molecular and Cellular Biochemistry, v. 202, p. 91-100, 1999. PMid:10705999. http:// dx.doi.org/10.1023/A:1007022329660

KRAUSHOFER, T.; SONTAG, G. Determination of some phenolic compounds in flax seed and nettle roots by HPLC with coulometric electrode array detection. European Food Research \& Technology, v. 215 , n. 6 , p. 529-533, 2002. http://dx.doi.org/10.1007/s00217002-0606-y

LI, X. et al. Separation and determination of secoisolariciresinol diglucoside oligomers and their hydrolysates in the flaxseed extract by high-performance liquid chromatography. Journal of Chromatography A, v. 1185, p. 223-232, 2008. PMid:18272161. http://dx.doi.org/10.1016/j.chroma.2008.01.066

MACIEL, L. M. B.; PONTES, D. F.; RODRIGUES, M. C. P. Efeitos da adição de farinha de linhaça no processamento de biscoito tipo cream craker. Alimentos e Nutrição, v. 19, n. 4, p. 385-92, 2008.

MALCOLMSON, L. J.; PRZYBYLSKI, R.; DAUN. J. K. Storage Stability of Milled Flaxseed. Journal of the American Oil Chemists Society, v. 77 , p. $235-238,2000$. http://dx.doi.org/10.1007/s11746-0000038-0

MANTHEY, F. A.; LEE, R. E.; HALL, C. A. Processing and cooking effects on lipid content and stability of a-linolenic acid in spaghetti containing ground flaxseed. Journal of Agricultural and Food Chemistry, v. 50, p. 1668-1671, 2002. PMid:11879055. http://dx.doi. org/10.1021/jf011147s

MARMER, W. N.; MAXWELL, R. J. Dry columm method for the quantitative extraction and simultaneous class separation of lipids from muscle tissue. Lipids, v. 16, p. 365-371, 1981. PMid:7253844. http://dx.doi.org/10.1007/BF02534964 
MEAGHER, L. P.; BEECHER, G. R. Assessment of data on the lignan content of foods. Journal of Food Composition and Analysis, v. 13, p. 935-947, 2000. http://dx.doi.org/10.1006/jfca.2000.0932

METCALFE, L. D.; SCHMITZ, A. A.; PELKA, J. R. Rapid preparation of fatty acid esters from lipids for gas chromatographic analysis. Analytical Chemistry, v. 12, p. 514, 1966. http://dx.doi.org/10.1021/ ac60235a044

MORIYA, H. et al. Oxidative stability of salmon and herring roe lipids and their dietary effect on plasma cholesterol levels of rats. Fisheries Science, v. 73, p. 668-674, 2007. http://dx.doi.org/10.1111/j.14442906.2007.01380.x

MORRIS, D. Essential nutrients and other functional compounds in flaxseed. Nutrition Today, v. 36, p. 159-162, 2001. http://dx.doi. org/10.1097/00017285-200105000-00012

NESBITT, P. D.; THOMPSON, L. U. Lignans in homemade and Commercial products containing flaxseed, Nutrition and Cancer, v. 29, p. 222-227, 1997. PMid:9457743. http://dx.doi. org/10.1080/01635589709514628

OOMAH, B. D.; MAZZA, G. Composition changes during commercial processing of flaxseed. Industrial Crops and Products, v. 9, p. 29-37, 1998. http://dx.doi.org/10.1016/S0926-6690(98)00010-7

OOMAH, B. D.; MAZZA, G. Effect of dehulling on chemical composition and physical properties of flaxseed. LebensmittelWissenschaft und-Technologie, v. 30, p. 135-140, 1997.

PROSKY, L. et al. Determination of insoluble, soluble and total dietary fiber in foods and products: intrelaboratory study. Journal of the Association of Official Analytical Chemists, v. 71, p. 1017-1023, 1988. PMid:2853153.

RICKARD, S. E.; THOMPSON, L. U. Health effects of flaxseed mucilage, lignans. Inform, v. 8, p. 860-865, 1997.

RICKARD, S. E. et al. Anticancer effects and avaiability of flaxseed lignans. In: FLAX INSTITUTE OF UNITED STATES, 57., 1998, Fargo. Proceedings... Flax Institute, 1998. p. 8-14.

ROSA, D. D. et al. Flaxseed, olive and fish oil influence plasmatic lipids, lymphocyte migration and morphometry of the intestinal of Wistar rats. Acta Cirurgica Brasileira, v. 25, p. 275-280, 2010. PMid:20498941. http://dx.doi.org/10.1590/S010286502010000300010

SACCO, S. M. et al. Flaxseed combined with low-dose estrogen therapy preserves bone tissue in ovariectomized rats. Menopause, v.16, n. 3, p. 545-554, 2009. PMid:19182694. http://dx.doi.org/10.1097/ gme.0b013e31818fc00a

SANTOS, F. L.; AZEREDO, V. B.; MARTINS, A. S. A. Effect of Supplying Food Complemented with Linseed on the Chemical Composition of Malaysian Shrimp (Macrobrachium rosenbergii). Ciência e tecnologia de alimentos, v. 27, n. 4, p. 851-855, 2007. http://dx.doi.org/10.1590/S0101-20612007000400027
SCIARRA, F.; TOSCANO, V. Role of estrogens in human benign prostatic hyperplasia. Archives of Andrology, v. 44, p. 213-220, 2000. http:// dx.doi.org/10.1080/014850100262191

SHAHIDI, F.; WANASUNDARA, U. N. Omega-3 fatty acid concentrates: nutritional aspects and production technologies. Food Science and Technology, v. 9, p. 230-240, 1998. PMid:21299575. http://dx.doi.org/10.1016/S0924-2244(98)00044-2

SIMBALISTA, R. L. et al. Consumption of a Flaxseed-Rich Food Is Not More Effective Than a Placebo in Alleviating the Climacteric Symptoms of Postmenopausal Women. The Journal of Nutrition, v. 140, p. 293-297, 2010.

SIMOPOULOS, A. P.; LEAF, A.; SALEM JUNIOR, N. Workshop statement on the essentiality of and recommended dietary intakes for omega- 6 and omega- 3 fatty acids-commentary on the workshop statement. Prostaglandins, Leukotrienes and Essential Fatty Acids, v. 63, n. 3, p. 123-124, 2000. PMid:10991765. http://dx.doi. org/10.1054/plef.2000.0177

SLAVIN, J. L.; JACOBS, D.; MARQUART, L. Grain processing and nutrition. Critical Reviews in Biotechnology, v. 21, p. 49-66, 2001. PMid:11307845. http://dx.doi.org/10.1080/20013891081683

STRUIJS, K. et al. The flavonoid herbacetin diglucoside as a constituent of the lignan macromolecule from flaxseed hulls. Phytochemistry, v. 68 , n. 8 , p. $1227-1235$, 2007. PMid:17141814. http://dx.doi. org/10.1016/j.phytochem.2006.10.022

THAKUR, G. et al. Effect of flaxseed gum on reduction of blood glucose and cholesterol in type 2 diabetic patients. International Journal of Food Science and Nutrition, v. 22, p. 1-11, 2009.

THOMPSON, L. U. Flaxseed, lignans, and cancer. In: CUNNANE, S. C.; THOMPSON, L. U. (Eds.). Flaxseed in Human Nutrition. Chicago: AOCS Press, 1995. p. 219-236.

THOMPSON, L. U. Flaxseed, lignans and cancer. In: CUNNANE, S. C.; THOMPSON, L. U. (Eds.). Flaxseed in Human Nutrition. 2nd ed. Illinois: AOCS Press, 2003. p. 194-222.

TORRES, E. A. F. S.; OKANI, E. T. Teste de TBA: Ranço em alimentos. Revista Nacional de Carne, v. 243, p. 68-76, 1997.

UNIVERSIDADE ESTADUAL DE CAMPINAS - UNICAMP. Tabela brasileira de composição de alimentos - TACO. Versão 2. 2. ed. Campinas: UNICAMP/NEPA, 2006.

VYNCKE, M. Evaluation of the direct thiobarbituric acid extraction method for determining oxidative rancidity in mackerel (Scomber scombrus L.). Fette Seifen Anstrichimittel, v. 77, n. 6, p. 239-240, 1975. http://dx.doi.org/10.1002/lipi.19750770610

WATT, B.; MERRILL, A. L. Composition of foods: raw, processed, prepared. Washington: Consumer and Food Economics Research, Divison/ Agricultural Service, 1963. (Agriculture Handbook, n. 8).

WESTCOTT, N. D.; MUIR, A. D., Variation in flaxseed lignan concentration with variety, location and year. In: FLAX INSTITUTE OF UNITED STATES, 56., 1996, Fargo. Proceedings... Flax Institute, 1996. p. 77-85. 